\title{
COMPETITIVENESS OF SPECIALIST VINEYARDS IN SELECTED EUROPEAN UNION COUNTRIES IN THE YEARS 2004-2015
}

\author{
Tadeusz Filipiak $^{1}$; Mariusz Maciejczak ${ }^{2}$ \\ ${ }^{1,2}$ Faculty of Economic Sciences, Warsaw University of Life Sciences - SGGW, Poland
}

\begin{abstract}
The paper aims to assess the competitiveness and efficiency of European farms specializing in viticultural production. The analysis was conducted for selected European Union countries using data from the years 2004-2015. In the analysed period, there was a large diversity in the resources used by these farms. The largest wine farms in terms of area were from Bulgaria, France, Spain, Austria and the Czech Republic; and in terms of labour from Bulgaria, France, the Czech Republic, Romania and Germany; while in terms of capital respectively in France, Germany, Italy, the Czech Republic and Austria. In the studied countries, the resources of land and capital increased, while labour remained at unchanged level. By calculating the competitiveness index, it was found that the French and German farms were the most competitive. The lowest competitiveness was found for Bulgarian, Portuguese, Spanish and Croatian farms. Based on the research, it is argued that obtaining income parity on the level of remuneration of hired employees does not guarantee development opportunities for farms specializing in viticultural production in selected EU countries.
\end{abstract}

Keys words: vineyards, competitiveness of farms, FADN, Europe.

JEL CODE: Q12, D24

\section{Acknowledgements}

This paper is based on the results of the project VITISMART (Toward a sustainable viticulture: Improved grapevine productivity and tolerance to abiotic and biotic stresses by combining resistant cultivars and beneficial microorganisms). The financing of this project by ERA-NET CO-FUND FACCE SURPLUS program through Polish National Centre for Research and Development (NCBiR) is acknowledged.

\section{Introduction}

In agriculture, similarly as in other sectors of the economy, there are processes of specialization and concentration of production. This is evident in the increase in the share of farms specializing in specific directions of production and the increase in their area ((Sobierajewska and Zietara, 2017)). An important issue regarding the functioning of business entities is their competitiveness. Research on competitiveness is carried out at 6 levels: global (world), regional (groups of countries e.g. EU), macro (economies of countries), meso (sectors, industries), micro (enterprises) and micro-micro (individual entrepreneurs or consumers) (Gorynia 2009).

Competitiveness is a complex economic category regarding the interaction between economic entities, sectors, or national or even global economies. It is determined on the basis of market share and / or changes in productivity and efficiency (Kleinhanss, 2015). It should therefore be assumed that competitiveness is defined as the farm's ability to grow. If the income is higher than the costs of production factors, then the farm owners are able to compete and stay on the market. Otherwise, they will take action to changed management conditions or cease to conduct a given activity and use production factors in a different way (Kleinhanss, 2015).

In the wine sector, there are many studies that relate to the analysis of competitiveness but winemaking enterprises in Europe, not farms (i.e. see Balogh and Jámbor, 2017). However, there are no microeconomic studies explicitly related to the economics and competitiveness of farms specializing in viticultural production. 


\section{Methodology}

The aim of the research was to determine the competitiveness and efficiency of farms specializing in viticulture in selected European Union countries in the years 2004-2014. The research covered farms specializing in viticulture production participating in the European Farm Accountancy Data Network (FADN) in selected countries. Accounting data of specialist vineyards from FADN were used as the study material. The viticulture farms - members of FAND system are classified in accordance with the Community Typology of Agricultural Holdings. Classification of farms is based on two criteria: business size and type of crops. Type of farm is determined by the share of Standard Output value of individual groups of farming operations in the total value of SO. Standard Output is defined as a 5 -year average output from specified plant or animal production from 1 ha or 1 animal during the year, under average production conditions typical for specific region. In FADN's field of analysis, there are farmsteads that produce ca. $90 \%$ Standard Output (SO) in specific region or country. Specialist vineyards were selected in accordance with grouping of general farm types for TF8 as type 3 Vineyards. The time range included data available in the FADN system for the years 2004-2015. All countries whose data was available in the FADN system were selected for the research. There were 14 countries, including: Bulgaria, Cyprus, the Czech Republic, Germany, Greece, Spain, France, Croatia, Hungary, Italy, Austria, Portugal, Romania and Slovenia.

The study presents the general characteristics of farms specialized in vinicultural production in selected EU countries, including land, labour and capital resources. Then, the income from the family farm was presented for these farms, and the competitiveness of farms growing vines and income parity was determined. Competitiveness of farms was estimated on the basis of the competitiveness index (Wk) elaborated by Werner Kleinhans (2015). Competitiveness index was defined as the ratio of farm income to the sum of estimated costs of using own production factors: own labour, land and capital. The costs of using own factors of production were estimated for: labour costs based on labour costs of hired employees, land costs based on rent of land and capital costs (excluding land) based on long-term government bond interest rates (risk-free). The value of the competitiveness index 'Wk1' means full coverage of the cost of production factors' own costs, while $W k<1$ means the incomplete coverage of the costs. The competitiveness index above 2 indicates the full competitive ability of the farm. This is consistent with the views of Biswanger (2011), who stated that a company capable of development should reach twice the rate of interest on loans. The income parity was in turn calculated as the ratio of the income from the family farm to the full-time employed person (FWU, Family Work Unit - 2120 hrs own work in a year) and the average remuneration of waged labour on the farm. In the paper, there are used descriptive statistics methods, including the absolute and relative dynamics of changes through applying linear and exponential regression analysis. The research data were obtained from the European FADN data and European Central Bank.

\section{Characteristics of surveyed farms specializing in viticultural production}

In the years 2004-2015 in the European countries, the average area of a farm specializing in viticulture was over 13.84 ha of utilized agricultural area (UAA) (Table 1). In the analysed period, the average area of viticultural farms increased from 13.31 ha to 14.16 ha of UAA, thus the average annual increase was about $0.6 \%$. 
Table 1

Resources of specialist vineyards in selected EU countries in 2004-2015

\begin{tabular}{|c|c|c|c|c|c|c|c|c|}
\hline \multirow{2}{*}{$\begin{array}{l}\text { Speci- } \\
\text { fica- } \\
\text { tion }\end{array}$} & \multirow[t]{2}{*}{ Country } & $\begin{array}{c}2004- \\
2006\end{array}$ & $\begin{array}{c}2007- \\
2009\end{array}$ & $\begin{array}{c}2010- \\
2012\end{array}$ & $\begin{array}{c}2013- \\
2015\end{array}$ & $\begin{array}{c}\text { Average } \\
2004- \\
2015\end{array}$ & $\begin{array}{r}\text { Averas } \\
\text { ch }\end{array}$ & $\begin{array}{l}\text { Innual } \\
\text { je }\end{array}$ \\
\hline & & \multicolumn{6}{|c|}{ absolute values } & $\%$ \\
\hline \multirow{15}{*}{ 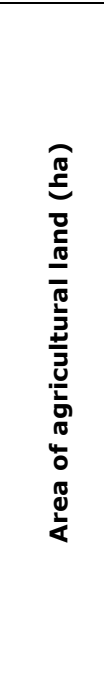 } & (BGR) Bulgaria* & - & 25.04 & 24.96 & 27.12 & 25.71 & 0.34 & 1.24 \\
\hline & (CYP) Cyprus* & 4.75 & 3.90 & 3.72 & 3.67 & 4.01 & -0.13 & -2.92 \\
\hline & (CZE) Czech Republic & 20.52 & 21.71 & 9.36 & 8.66 & 15.06 & -1.39 & -9.40 \\
\hline & (DEU) Germany & 10.60 & 11.13 & 13.04 & 12.79 & 11.89 & 0.28 & 2.43 \\
\hline & (ELL) Greece & 4.68 & 4.49 & 4.36 & 5.12 & 4.66 & 0.05 & 0.81 \\
\hline & (ESP) Spain & 17.41 & 22.48 & 24.21 & 22.78 & 21.72 & 0.60 & 2.92 \\
\hline & (FRA) France & 24.81 & 24.42 & 24.12 & 24.39 & 24.44 & -0.05 & -0.22 \\
\hline & (HRV) Croatia* & - & - & - & 4.33 & 4.33 & 0.00 & -0.11 \\
\hline & (HUN) Hungary & 8.77 & 9.82 & 10.76 & 11.33 & 10.17 & 0.28 & 2.75 \\
\hline & (ITA) Italy & 7.16 & 7.81 & 8.18 & 8.89 & 8.01 & 0.18 & 2.29 \\
\hline & (OST) Austria & 23.24 & 17.77 & 14.03 & 12.72 & 16.94 & -1.16 & -6.54 \\
\hline & (POR) Portugal & 8.96 & 9.75 & 10.38 & 10.75 & 9.96 & 0.21 & 2.10 \\
\hline & (ROU) Romania* & - & 9.86 & 10.45 & 6.92 & 9.08 & -0.37 & -4.95 \\
\hline & (SVN) Slovenia* & 4.66 & 5.06 & 4.32 & 4.19 & 4.54 & -0.08 & -1.75 \\
\hline & (EU) European Union & 13.31 & 14.05 & 13.85 & 14.16 & 13.84 & 0.08 & 0.57 \\
\hline \multirow{15}{*}{ 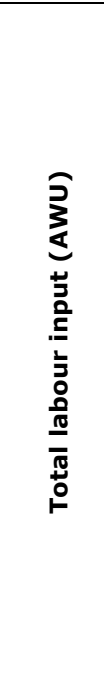 } & (BGR) Bulgaria* & - & 6.74 & 5.43 & 4.66 & 5.61 & -0.32 & -5.81 \\
\hline & (CYP) Cyprus* & 0.96 & 0.81 & 1.27 & 1.30 & 1.09 & 0.05 & 4.27 \\
\hline & (CZE) Czech Republic & 3.12 & 3.60 & 1.97 & 2.02 & 2.68 & -0.14 & -4.94 \\
\hline & (DEU) Germany & 2.32 & 2.47 & 2.46 & 2.53 & 2.44 & 0.02 & 0.80 \\
\hline & (ELL) Greece & 1.29 & 1.27 & 1.11 & 0.95 & 1.16 & -0.04 & -3.36 \\
\hline & (ESP) Spain & 1.36 & 1.37 & 1.42 & 1.45 & 1.40 & 0.01 & 0.81 \\
\hline & (FRA) France & 2.70 & 2.71 & 2.76 & 2.98 & 2.79 & 0.03 & 0.96 \\
\hline & (HRV) Croatia* & - & - & - & 1.85 & 1.85 & -0.09 & -4.69 \\
\hline & (HUN) Hungary & 1.97 & 1.78 & 2.01 & 2.27 & 2.01 & 0.04 & 1.83 \\
\hline & (ITA) Italy & 1.26 & 1.29 & 1.26 & 1.21 & 1.25 & -0.01 & -0.64 \\
\hline & (OST) Austria & 1.63 & 1.56 & 1.45 & 1.83 & 1.62 & 0.01 & 0.94 \\
\hline & (POR) Portugal & 1.90 & 1.76 & 1.80 & 1.84 & 1.82 & -0.01 & -0.27 \\
\hline & (ROU) Romania* & & 3.14 & 2.43 & 2.14 & 2.57 & -0.18 & -5.59 \\
\hline & (SVN) Slovenia* & 2.09 & 1.97 & 2.15 & 1.46 & 1.90 & -0.07 & -3.97 \\
\hline & (EU) European Union & 1.67 & 1.74 & 1.68 & 1.72 & 1.70 & 0.00 & 0.14 \\
\hline \multirow{15}{*}{ 旁 } & (BGR) Bulgaria* & - & 268.86 & 310.30 & 308.87 & 296.01 & 8.88 & 2.94 \\
\hline & (CYP) Cyprus* & 132.90 & 126.18 & 228.75 & 131.76 & 154.90 & 2.39 & 1.00 \\
\hline & (CZE) Czech Republic & 249.12 & 310.37 & 229.38 & 469.83 & 314.67 & 18.17 & 5.13 \\
\hline & (DEU) Germany & 474.74 & 514.36 & 536.37 & 582.29 & 526.94 & 11.33 & 2.15 \\
\hline & (ELL) Greece & 91.03 & 99.31 & 91.30 & 103.93 & 96.39 & 1.18 & 0.96 \\
\hline & (ESP) Spain & 176.22 & 216.06 & 218.26 & 226.88 & 209.36 & 5.25 & 2.59 \\
\hline & (FRA) France & 501.10 & 548.28 & 588.72 & 619.26 & 564.34 & 13.27 & 2.36 \\
\hline & (HRV) Croatia* & - & - & - & 237.56 & 237.56 & -21.76 & -8.87 \\
\hline & (HUN) Hungary & 142.57 & 142.91 & 193.91 & 213.59 & 173.25 & 8.59 & 4.86 \\
\hline & (ITA) Italy & 270.70 & 308.47 & 374.10 & 419.71 & 343.24 & 16.45 & 4.79 \\
\hline & (OST) Austria & 296.17 & 307.76 & 292.03 & 325.84 & 305.45 & 2.69 & 0.91 \\
\hline & (POR) Portugal & 101.17 & 112.58 & 153.78 & 185.22 & 138.19 & 9.75 & 7.04 \\
\hline & (ROU) Romania* & - & 184.73 & 104.91 & 109.61 & 133.09 & -9.08 & -8.97 \\
\hline & (SVN) Slovenia* & 185.34 & 182.10 & 210.51 & 241.56 & 206.65 & 8.12 & 3.85 \\
\hline & (EU) European Union & 282.96 & 314.93 & 354.03 & 382.90 & 333.70 & 11.21 & 3.37 \\
\hline
\end{tabular}

* data for Slovenia since 2005, for Bulgaria and Romania since 2007 and Croatia since 2013

Source: authors' study based on FADN data

In the analysed period, the largest UAA was characterized by Bulgarian (25.7 ha), French (24.4 ha), Spanish (21.7 ha), Austrian (16.9 ha) and Czech (15.1 ha) farms. In turn, the smallest area of 
agricultural land was characterized by Cypriot ( $4 \mathrm{ha}$ ), Croatian (4.3 ha), Slovenian (4.5 ha) and Greek (4.7 ha) farms. In 2004-2015, in relative terms, the increase in the area of farms specializing in viticulture was recorded in Spanish (annual average of $2.9 \%$ ), Hungarian $(2.8 \%)$, German $(2.4 \%)$ and Italian (2.3\%), Portuguese $(2.1 \%)$ and Bulgarian (1.2\%) farms. In the remaining countries was observed decrease in the area of farms. The largest relative decrease was recorded in Czech farms (annual average $-9.4 \%$ ), Austrian (-6.5\%), Romanian (- $5.0 \%$ ) and Cypriot (- $3 \%)$.

In the years 2004-2015, in European farms specializing in viticulture, work expenditures on average were on the same level, and amounted to about 1.7 of Annual Working Unit (AWU). The largest labour resources were in farms from Bulgaria (5.6 AWU), France (2.8 AWU), Czech (2.7 $\mathrm{AWU}$ ), Romania (2.6 AWU) and Germany (2.4 AWU). In turn, the smallest work resources were characterized by Cypriot (1.09 AWU), Greek (1.16 AWU), Italian (1.25 AWU) and Spanish (1.4 $\mathrm{AWU}$ ) farms. In the analysed period, in relative terms, the largest increase in labour expenditure per farm was recorded in Cypriot (annual average of $4.3 \%$ ), Hungarian (1.8\%), French and Austrian (0.9\%) and Spanish and German (0.8\%) farms. \%). The largest decrease in relative terms was recorded in Bulgarian farms (annual average - $5.8 \%$ ), Romanian (- $5.6 \%$ ), Czech ($4.9 \%$ ) and Slovenian (- $4 \%)$.

In the years 2004-2015, on average, in the EU Member States, in farms specializing in viticulture, there was an increase in the value of total assets from approx. $282.96 \mathrm{k}$ Euro to approx. $382.90 \mathrm{k}$ Euro, i.e. average annually by approx. $3.37 \%$ (nominal value). In the analysed period, in the majority of farms, there was an increase in the value of total assets, except for Romanian and Croatian farms. In relative terms, the largest increase in the value of total assets was recorded in Portuguese farms (on average by $7.04 \%$ ), Czech (by $5.13 \%$ ), Hungarian (by $4.86 \%$ ) and Italian (by $4.79 \%$ ). In absolute terms, the largest increase in total assets was recorded in Czech farms (annual average of 18.17 Euro), Italian (by $16.45 \mathrm{k}$ Euro), French (13.27 k Euro) and German (by 11.33 k Euro). A decrease in the value of assets was observed in Croatian and Romanian farms. In relative terms, for these farms the decline was on average $8.9 \%$. In the analysed period, the largest farms specializing in viticulture in terms of total property value were observed in France (on average around 555.34 k Euro), Germany (526.94 k Euro), Italy (343.24 k Euro), the Czech Republic (314.67 k Euro) and Austria (305.45 k Euro). The smallest farms were recorded in Greece (on average 96.39 k Euro), Romania (133.09 k Euro), Portugal (138.19 k Euro) and Cyprus (154.90 k Euro).

\section{Farm income of surveyed farms specializing in viticultural production}

In the FADN farm accountancy system, income from a family farm is a fee for the involvement of own production factors (land, labour and capital for the farm's operational activity and a risk fee for the farm operator). In the analyzed countries, the income from farms specializing in viticultural production increased from 21.97 k Euro to 24.72 k Euro, i.e., on average, by $3.03 \%$ per annum. In the analysed period, the largest increase in income observed on Portuguese farms (on average about $6.60 \%)$, Spanish (5\%), Italian (3.5\%), French (3.4\%) and German (2.7\%). In relative terms, the largest decrease in income was observed on Croatian (- $9.9 \%)$, Slovenian $(-7.2 \%)$, Greek (- $6.1 \%)$ and Czech (- $2.9 \%)$ farms. In the analysed period, the highest income from farms specializing in viticulture was obtained in French farms (on average, approx. $51.5 \mathrm{k}$ Euro), German (41.1 k Euro), Austrian (22.4 k Euro) and Italian (20.2 k Euro). The smallest incomes on farms 
were in Bulgarian farms (average annual 860 Euro), Cypriot (4.6 k Euro) and Croatian (about $4.8 \mathrm{k}$ Euro). In some years, for some countries, there was a loss of income from the farm.

Farm Net Income of specialist vineyards in selected EU countries in 2004-2015

\begin{tabular}{|c|c|c|c|c|c|c|c|c|}
\hline \multirow[t]{2}{*}{$\begin{array}{c}\text { Specificati } \\
\text { on }\end{array}$} & \multirow[t]{2}{*}{ Country } & $\begin{array}{l}2004- \\
2006\end{array}$ & $\begin{array}{l}2007- \\
2009\end{array}$ & $\begin{array}{l}2010- \\
2012\end{array}$ & $\begin{array}{l}2013- \\
2015\end{array}$ & $\begin{array}{l}\text { Averag } \\
\text { e 2004- } \\
2015\end{array}$ & \multicolumn{2}{|c|}{$\begin{array}{l}\text { Average } \\
\text { annual } \\
\text { change }\end{array}$} \\
\hline & & \multicolumn{6}{|c|}{ absolute values } & $\%$ \\
\hline \multirow{15}{*}{$\begin{array}{l}\text { Farm Net } \\
\text { Income }\end{array}$} & (BGR) Bulgaria* & - & -1.44 & -1.36 & 5.37 & 0.86 & 1.23 & $x$ \\
\hline & (CYP) Cyprus* & 2.68 & 5.99 & 6.91 & 2.83 & 4.60 & 0.15 & $x$ \\
\hline & (CZE) Czech Republic & 16.75 & 22.02 & 14.39 & 17.18 & 17.59 & -0.32 & -2.88 \\
\hline & (DEU) Germany & 38.39 & 41.05 & 42.64 & 50.42 & 43.12 & 1.21 & 2.74 \\
\hline & (ELL) Greece & 16.03 & 14.86 & 11.93 & 9.17 & 13.00 & -0.75 & -6.05 \\
\hline & (ESP) Spain & 13.34 & 15.32 & 18.63 & 20.64 & 16.98 & 0.81 & 4.96 \\
\hline & (FRA) France & 44.88 & 45.02 & 54.54 & 61.58 & 51.50 & 1.86 & 3.36 \\
\hline & (HRV) Croatia* & - & - & - & 4.77 & 4.77 & -0.54 & -9.87 \\
\hline & (HUN) Hungary & 7.48 & 7.05 & 10.90 & 12.20 & 9.40 & 0.56 & $x$ \\
\hline & (ITA) Italy & 17.25 & 18.99 & 19.95 & 24.63 & 20.20 & 0.74 & 3.52 \\
\hline & (OST) Austria & 22.66 & 23.29 & 23.86 & 19.91 & 22.43 & -0.28 & -1.44 \\
\hline & (POR) Portugal & 8.63 & 9.22 & 13.98 & 14.87 & 11.67 & 0.73 & 6.60 \\
\hline & (ROU) Romania* & - & 5.54 & 8.20 & 10.54 & 8.09 & 1.36 & $x$ \\
\hline & (SVN) Slovenia* & 8.43 & 15.94 & 11.79 & 6.26 & 10.80 & -0.68 & -7.16 \\
\hline & (EU) European Union & 21.97 & 22.52 & 25.24 & 29.17 & 24.72 & 0.78 & 3.03 \\
\hline
\end{tabular}

Source: authors' study based on FADN data

\section{Competitiveness of surveyed farms specializing in viticultural production}

It was found that the competitiveness index of analysed European farms specializing in viticultural production did not reach the level above 2 . In the analysed period, the competitiveness index above 1 was only on French (on average 1.17) and German (1.04) farms. In other countries, the competitiveness index was below 1 (table 3 ).

The lowest competitiveness index characterized Bulgarian (0.12), Portuguese (0.16), Croatian (0.30), Cypriot (0.34) and Hungarian (0.32) farms. A negative competitiveness index was recorded in those years and in the countries where farms obtained a loss of activity. In the years 20042015 , the increase in the competitiveness index was recorded on Spanish farms (annual average of $8.49 \%$ ), Italian (6.06 \%), Greek (4.35\%), Portuguese (by $3.65 \%$ ) and French ( by $1.71 \%$ ). The level of competitiveness index in German farms practically has the same level in the analyzed period (on average 1.04).

In the analysed period, the decline in the competitiveness index was recorded in Czech farms (annual average $-9.30 \%$ ), Austrian $(-6.53 \%$ ) and Slovenian $(-2.15 \%)$. It was found that here were large fluctuations in the level of the competitiveness index in European farms specializing in viticultural production. The largest coefficient of variation of the competitiveness index was in Bulgarian (368.26 \%) and Cypriot $(101.16 \%)$ farms. The smallest coefficient of variation of the competitiveness index was observed on German (12.23\%), Slovenian (13.99\%) and French (18.09 \%) farms. 


\section{Income parity and competitiveness of specialist vineyards in selected EU} countries in the years 2004-2015

\begin{tabular}{|c|c|c|c|c|c|c|c|c|}
\hline \multirow{3}{*}{ 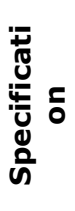 } & \multirow{3}{*}{ Country } & \multicolumn{5}{|c|}{ Years } & \multirow{2}{*}{\multicolumn{2}{|c|}{$\begin{array}{l}\text { Average } \\
\text { annual } \\
\text { change }\end{array}$}} \\
\hline & & $\begin{array}{l}2004- \\
2006\end{array}$ & $\begin{array}{l}2007- \\
2009\end{array}$ & $\begin{array}{c}2010- \\
2012\end{array}$ & $\begin{array}{l}2013- \\
2015\end{array}$ & $\begin{array}{l}\text { Averag } \\
\text { e 2004- }\end{array}$ & & \\
\hline & & \multicolumn{6}{|c|}{ absolute values } & $\%$ \\
\hline \multirow{15}{*}{ 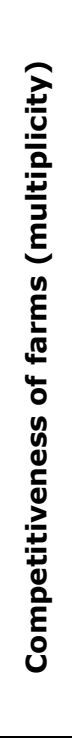 } & (BGR) Bulgaria & - & 0.09 & -0.02 & 0.30 & 0.12 & 0.03 & $x$ \\
\hline & (CYP) Cyprus & 0.24 & 0.48 & 0.52 & 0.11 & 0.34 & 0.00 & $x$ \\
\hline & (CZE) Czech Republic & 1.06 & 1.03 & 0.52 & 0.64 & 0.81 & -0.07 & -9.30 \\
\hline & (DEU) Germany & 1.05 & 1.01 & 1.07 & 1.02 & 1.04 & 0.00 & -0.26 \\
\hline & (ELL) Greece & 0.59 & 0.58 & 0.56 & 0.92 & 0.66 & 0.03 & 4.35 \\
\hline & (ESP) Spain & 0.17 & 0.17 & 0.27 & 0.35 & 0.24 & 0.02 & 8.49 \\
\hline & (FRA) France & 1.11 & 1.05 & 1.24 & 1.30 & 1.17 & 0.02 & 1.71 \\
\hline & (HRV) Croatia & - & - & - & 0.30 & 0.30 & 0.00 & -0.11 \\
\hline & (HUN) Hungary & 0.29 & 0.23 & 0.36 & 0.40 & 0.32 & 0.01 & - \\
\hline & (ITA) Italy & 0.42 & 0.41 & 0.47 & 0.74 & 0.51 & 0.03 & 6.06 \\
\hline & (OST) Austria & 0.81 & 0.78 & 0.71 & 0.44 & 0.69 & -0.04 & -6.53 \\
\hline & (POR) Portugal & 0.13 & 0.14 & 0.19 & 0.18 & 0.16 & 0.00 & 3.65 \\
\hline & (ROU) Romania & - & 0.36 & 0.47 & 0.33 & 0.39 & 0.02 & $x$ \\
\hline & (SVN) Slovenia & 0.28 & 0.82 & 0.59 & 0.37 & 0.53 & -0.02 & -2.15 \\
\hline & (EU) European Union & 0.57 & 0.57 & 0.61 & 0.69 & 0.61 & 0.01 & 1.84 \\
\hline \multirow{15}{*}{ 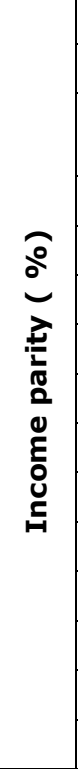 } & (BGR) Bulgaria & - & 78.67 & 25.71 & 45.05 & 49.81 & -5.72 & $x$ \\
\hline & (CYP) Cyprus & 36.50 & 85.93 & 81.22 & 55.39 & 64.76 & 3.62 & $x$ \\
\hline & (CZE) Czech Republic & 205.27 & 169.60 & 83.75 & 119.55 & 144.54 & 12.30 & -9.63 \\
\hline & (DEU) Germany & 157.55 & 156.21 & 154.08 & 154.01 & 155.46 & -0.83 & -0.51 \\
\hline & (ELL) Greece & 184.78 & 161.62 & 167.53 & 182.89 & 174.21 & -0.17 & -0.09 \\
\hline & (ESP) Spain & 98.80 & 102.84 & 108.37 & 117.43 & 106.86 & 1.80 & 1.86 \\
\hline & (FRA) France & 128.45 & 117.85 & 136.69 & 138.74 & 130.43 & 1.39 & 0.87 \\
\hline & (HRV) Croatia & - & - & - & 45.64 & 45.64 & 1.44 & 2.76 \\
\hline & (HUN) Hungary & 50.17 & 158.72 & 175.25 & 266.89 & 162.76 & 21.50 & $x$ \\
\hline & (ITA) Italy & 99.02 & 104.74 & 109.61 & 137.57 & 112.74 & 3.88 & 3.28 \\
\hline & (OST) Austria & 136.84 & 138.77 & 124.92 & 70.35 & 117.72 & -7.47 & -7.39 \\
\hline & (POR) Portugal & 104.80 & 99.05 & 133.51 & 137.29 & 118.66 & 3.97 & 3.52 \\
\hline & (ROU) Romania & - & 155.43 & 52.49 & 375.81 & 194.58 & 54.39 & $x$ \\
\hline & $(\mathrm{SVN})$ Slovenia & 56.18 & 113.85 & 74.14 & 49.89 & 75.09 & -4.19 & -5.55 \\
\hline & (EU) European Union & 104.39 & 120.86 & 121.33 & 127.98 & 118.64 & 2.08 & 1.80 \\
\hline
\end{tabular}

* data for Slovenia since 2005, for Bulgaria and Romania since 2007 and Croatia since 2013

Source: authors' study based on FADN data

In the analysed period the highest indicator of income parity in specialist vineyards in selected EU countries was observed in farms from Romania (194.58\%), Greece (174.2\%), Hungary $(162.76 \%)$, Germany $(155.46 \%)$, Czech $(144.54 \%)$ and France $(130.43)$. The smallest rate of income parity index was found in Croatian (45.64 \%), Bulgarian (49.81\%), Cypriot $(64.76 \%)$ and Slovenian $(75.09 \%)$ farms. In the analysed period, the highest increase in income parity was observed in Portuguese farms (on average by $3.52 \%$ ), Italian (by $3.28 \%$ ) and Croatian (by $2.76 \%$ ). On the other hand, the largest decrease in parity was recorded on Czech farms (on average annually by $-9.63 \%)$, Austrian (- $7.39 \%)$ and Slovenian $(-5.55 \%)$. 


\section{Conclusions}

The wine sector plays an important role in the national economies of many countries, especially in areas with favourable conditions for viticultural production. In the years 2004-2015, there was a slight increase in the area of arable land in European specialist vineyard farms, and there was no change in labour resources too. An increase in the value of total property was observed. In the analysed period, a large variation in the level and dynamics of income could be observed. Accordingly, the competitiveness index slightly increased and reached the level of 0.69. In the analysed years, the competitiveness index in none of the countries reached the level of 2 and above. This means that farms specializing in viticulture in EU countries have very limited developmental abilities. On the basis of the analysis of the income parity of the surveyed farms, it should be stated that the income from the farm at the parity level does not determine the competitive ability of the farm too. This is largely due to the large variation and relatively low level of wage labour costs. Therefore, it is argued that the income parity does not guarantee achieving competitive capabilities of European specialist vineyard farms.

\section{Bibliography}

1. Balogh J., Jambor A., 2017: "The Global Competitiveness of European Wine Producers", British Food Journal, Vol. 119 Issue: 9, pp. 2076-2088, https://doi.org/10.1108/BFJ-12-2016-0609

2. Biswanger H.Ch., 2011: "Spirala wzrostu, pieniadz, energia i kreatywnosc $w$ dynamice

3. procesow rynkowych", ZYSK I S-KA, Poznań.

4. Goraj L., Bocian M., Osuch D., Smolik A., 2015: „Parametry techniczno-ekonomiczne według grup gospodarstw rolnych uczestniczących w polskim FADN w latach 2008-2014", IERiGZ-PIB, Warszawa.

5. Kleinhanss W., 2015: „Konkurencyjnosc głownych typow gospodarstw rolniczych w Niemczech, Zagadnienia Ekonomiki Rolnej, nr 1, pp. 25-41.

6. Sobierajewska J., Ziętara W., 2017: „Konkurencyjnosc polskich gospodarstw ogrodniczych”. Roczniki Ekonomii Rolnictwa i Rozwoju Obszarow Wiejskich 104(3), pp. 21-32. 